\title{
Pemanfaatan bahan makanan lokal kentang (Solanum tuberosum l), ikan lele (Clarias, sp) dan brokoli (Brassica oleracea l) dalam bentuk snack kroket untuk balita dengan status gizi kronis
}

Utilization of local foodstuffs potatoes (Solanum tuberosum l), catfish (Clarias, sp), and broccoli (Brassica oleracea l) in the form of snacks croquettes for toddlers with characteristics of chronic nutritional status

\author{
Niken Yunia Rifqi ${ }^{1)}$, Sugeng Iwan ${ }^{1)}$, Nurul Hakimah ${ }^{1 *}$ \\ ${ }^{1}$ Program Studi Pendidikan Profesi Dietisien, Jurusan Gizi, Poltekkes Kemenkes Malang, Jawa Timur \\ *E-mail korespondensi: hakimahnurul89@gmail.com
}

Informasi Artikel:

Dikirim: 28/06/2020; disetujui: 10/09/2020; diterbitkan: 10/03/2021

\begin{abstract}
The percentage of children under five in $R W 2$ with the characteristics of chronic nutritional status is 8 people or $73 \%$. Chronic indicators describe the nutritional problems of children under five in the long term, due to low $B W / U$ index, short $B W / U$, normal BW/TB. The purpose of this study was to determine the nutritional quality, protein quality of the formula. knowing the best treatment, organoleptic quality of the formula for the use of local food ingredients: potato (Solanum tuberosum L), catfish (Clarias Sp), and broccoli (Brassica oleracea L). This type of research is experimental with a completely randomized design (CRD). The level of treatment was the ratio of potato: catfish: broccoli, namely P1 (40:30:30), and P2 (30:45:25). The croquette snack formula at treatment levels 1 and 2 had nutritional values, namely energy of 156 $\mathrm{Kcal}$ and $125 \mathrm{Kcal}$. The value of $P 1$ protein is 7.6 grams, $P 2$ is 8.85 grams, $P 1$ fat is 6.36 grams and $P 2$ is 2.76 grams. Nutritional content in $P 1$ is better than $P 2$ seen from the calculation of nutritional value and protein quality. The digestibility quality of $P 1$ was higher at 94.4. The level of treatment P1 (40:30:30) was the best treatment level in terms of the number of $\mathrm{Nh}$, which was 0.53. Organoleptic quality at P1 was preferred by panelists for the attributes of color, taste, texture, and aroma of potato croquettes, which obtained an average value on a scale of 3. This study concluded that the addition of catfish increased the protein and phosphorus content in the croquette formula. The addition of broccoli increases the content of vitamin $C$ and phosphorus. $P 1$ nutritional quality (energy, protein, fat, carbohydrates). The best treatment is treatment 1 with a higher value than treatment 2 and the organoleptic quality of the P1 formula is preferred by the panelists than $P 2$.
\end{abstract}

Keywords: chronic nutritional, local food, snack croquettes

\begin{abstract}
ABSTRAK
Persentase Balita di RW 2 dengan Karakteristik Status gizi kronis sebanyak 8 orang atau $73 \%$. Indikator kronis menggambarkan masalah gizi anak balita dalam jangka waktu panjang, akibat indeks BB/U kurang, TB/U pendek, BB/TB normal. Tujuan penelitian ini adalah mengetahui mutu gizi, mutu protein formula. Mengetahui Perlakuan terbaik, mutu organoleptik formula pemanfaatan bahan makanan lokal kentang (Solanum tuberosum L), ikan lele (Clarias Sp) dan brokoli (Brassica oleracea L). Jenis penelitian adalah eksperimental dengan desain Rancangan Acak Lengkap
\end{abstract}


(RAL). Taraf perlakuan adalah perbandingan kentang : Ikan lele : Brokoli yaitu $\mathrm{P}_{1}$ (40:30:30), dan $\mathrm{P}_{2}$ (30:45:25). Formula snack kroket taraf perlakuan 1, dan 2 memiliki nilai gizi yaitu energi sebesar $156 \mathrm{Kkal}$, dan $125 \mathrm{Kkal}$. Nilai Protein P1 sebesar 7,6 gram, P2 8,85 gram, lemak P1 6,36 gram dan P2 sebesar 2,76 gram. Kandungan gizi pada P1 lebih baik dibandingkan dengan P2 dilihat dari hasil perhitungan nilai gizi dan mutu protein. Mutu Cerna P1 lebih tinggi yaitu sebesar 94,4.Taraf perlakuan $\mathrm{P}_{1}$ (40:30:30) merupakan taraf perlakuan terbaik dilihat dari Jumlah Nh yaitu 0,53. Mutu Organoleptik pada P1 lebih disukai panelis terhadap atribut warna, rasa, tekstur dan aroma kroket kentang yaitu memperoleh nilai rata-rata skala 3. Kesimpulan penelitian ini adalah penambahan ikan lele meningkatkan kandungan protein dan fosfor pada formula kroket. Penambahan brokoli meningkatkan kandungan vitamin $\mathrm{C}$ dan fosfor. Mutu gizi P1 (energi, protein, lemak, karbohidrat). Perlakuan terbaik yaitu perlakuan 1 dengan nilai lebih tinggi dari pada perlakuan 2 dan mutu organoleptik formula P1 lebih disukai panelis daripada $\mathrm{P} 2$.

Kata Kunci : gizi kronis, makanan lokal, snack kroket

\section{PENDAHULUAN}

Hasil data PGZ pada bulan Agustus 2020, prevalensi masalah gizi balita di kelurahan Merjosari cukup tinggi di wilayah kerja Puskesmas Dinoyo Kota Malang yaitu $13,4 \%$ balita pendek, $8,43 \%$ balita sangat pendek, $1,42 \%$ balita BGM (Bawah Garis Merah), 6,45\% balita BBK (Berat Badan Kurang), 3,19\% balita kurus, $0,14 \%$ balita sangat kurus, dan $8,15 \%$ balita gemuk.

Masalah gizi balita tertinggi ketiga yaitu RW 2 (posyandu Nusa Indah) dengan prevalensi balita dengan masalah gizi balita pendek $1,7 \%$, balita sangat pendek sebesar $0,64 \%$, balita dengan BBK 0,99\%, Balita dengan BGM sebesar $0,07 \%$ dan balita dengan gemuk sebesar $0,6 \%$.

Karakteristik Status gizi di RW 2 yaitu akut kronis sebanyak 1 orang atau 9\%, Tidak akut tapi kronis sebanyak 8 orang atau $73 \%$, dan akut tidak kronis sebanyak 18\%. Balita yang termasuk dalam kategori masalah gizi kronis yang artinya anak balita tersebut status gizi berdasarkan indeks TB/U kurang, BB/U normal, dan $\mathrm{BB} / \mathrm{TB}$ normal. Indikator kronis menggambarkan masalah gizi anak balita dalam jangka waktu panjang masalah gizi kronis dapat terjadi juga apabila indeks BB/U kurang, TB/U pendek, BB/TB normal, yang mana keadaan gizi anak saat ini baik, tetapi anak tersebut mengalami gizi kronis yang berkaitan dengan BB anak proporsionalnya dengan TB (Supariasa, 2016). Hal ini digunakan untuk menentukan kebijakan atau perencanaan intervensi program gizi yang sesuai untuk penanganan masalah gizi di daerah RW 2 kelurahan Merjosari. Salah satu penanganan masalah gizi pada balita khususnya dengan masalah gizi kronis yaitu melakukan pemberian makanan tambahan pada balita, dengan pendekatan inovasi produk yang mengandung tinggi protein.

Ikan lele (Clarias gariepinus) merupakan salah satu jenis ikan air tawar yang kaya protein dan asam amino essensial seperti lisin dan leusin yang dibutuhkan oleh anak untuk mendukung pertumbuhan, perbaikan jaringan, menghasilkan antibodi, dan membantu penyerapan kalsium. Ikan lele memiliki kadar protein cukup tinggi, yaitu 17,7-26,7\% dan lemaknya berkisar 0,95 $11,5 \%$ (Nurilmala, Nurjanah, \& Utomo, 2009).

Sebagian vitamin dan mineral yang terkandung dalam sayuran berperan untuk membantu proses-proses metabolisme di dalam tubuh, sedangkan antioksidan mampu menangkal senyawa-senyawa hasil oksidasi, radikal bebas. Tomat dan brokoli merupakan contoh sayuran yang kaya akan vitamin dan mineral. Kedua sayuran ini selain sebagai sumber vitamin $\mathrm{C}$, juga mengandung antioksidan yang cukup tinggi (Rini \& Hastawati, 2017). Tomat mengandung 2083 $\mu \mathrm{g}$ vitamin A dan $34 \mathrm{~g}$ Vitamin C, sedangkan Brokoli mengandung 189,9 Vitamin A dan 89.2 Vitamin C (Rini \& Hastawati, 2017.) 


\section{METODE}

\section{Alat dan bahan}

Alat yang digunakan untuk pengolahan Kroket yaitu Baskom stainless, timbangan digital, pisau, piring, risopan, wajan, sendok, talenan, mangkuk, cup makanan, sendok plastik.

Bahan yang digunakan untuk pembuatan Kroket yaitu Kentang, ikan lele, brokoli, telur ayam, susu fullcream merek "Dancow", garam, merica, tepung terigu, tepung panir, bawang bombai, bawang merah, bawang putih.

\section{Prosedur pembuatan}

a) Cara Membuat isian Kroket:

1. Bersihkan ikan lele

2. Kukus ikan lele selama kurang lebih 20 menit

3. Rebus brokoli kurang lebih 5 menit

4. Cincang brokoli

5. Panaskan sedikit minyak untuk menumis

6. Tumis bawang putih, bawang merah, bawang bombai sampai harum

7. Masukkan ikan lele yang sudah disuwir, aduk hingga berubah warna

8. Tambahkan brokoli, aduk aduk.

9. Masukkan kecap manis, merica, garam.

10. Tambahkan daun bawang, aduk sampai tercampur rata masak sampai air mengering, dan angkat.

b) Cara membuat kulit Kroket:

1. Kentang kupas dan dibersihkan dengan air

2. Kentang kukus selama 15 menit, tiriskan

3. Dihaluskan menggunakan garpu atau sendok.

4. Tambahkan susu, tepung terigu, kuning telur, dan merica.

5. Porsi sesuai kebutuhan lalu nanti isi dengan isian kroket. c) Pembuatan Kroket

1. Ambil adonan kulit, timbang sesuai porsi, taruh di telapak tagan, pipihkan.

2. Beri isi sesuai porsi yang sudah ditimbang, bentuk oval lonjong, lakukan hingga habis

3. Gulingkan ke tepung panir, celupkan ke putih telur, gulingkan lagi ke tepung panir.

4. Simpan sebentar dalam kulkas agar tepung menempel

5. Panaskan minyak, goreng kroket sampai matang dan berwarna kecokelatan.

\section{Desain penelitian}

Jenis penelitian yang digunakan adalah eksperimental dengan desain Rancangan Acak Lengkap (RAL) menggunakan 2 taraf perlakuan yaitu kentang : Ikan lele : Brokoli yaitu $\mathrm{P}_{1}(40: 30: 30)$, dan $\mathrm{P}_{2}(30: 45: 25)$.

\section{Analisis perlakuan terbaik}

Penentuan taraf perlakuan terbaik menggunakan metode indeks efektivitas. Panelis diminta untuk memberikan pendapat tentang variabel yang mempengaruhi mutu dan memberikan nilai pada variabel tersebut. Panelis dalam penelitian ini harus mempunyai kriteria sebagai berikut:

a. Panelis semi terlatih

b. Panelis paham tentang variabel penting yang terdapat pada produk

c. Panelis diharapkan untuk mengisi formulir penilaian perlakuan terbaik

\section{Uji mutu organoleptik}

Dilakukan dengan metode uji kesukaan (hedonic scale test). Panelis dimintakan tanggapan pribadinya tentang kesukaan atau sebaliknya (ketidaksukaan). Disamping panelis mengemukakan tanggapan senang, suka atau kebalikannya, mereka juga mengemukakan tingkat kesukaannya. Tingkat - tingkat kesukaan ini disebut skala hedonik dar nilai 4 (sangat suka), 3(suka), 2 (tidak suka) dan 1 (sangat tidak suka). Panelis yang digunakan untuk uji organoleptik adalah panelis semi terlatih sebesar 15 panelis (pegawai puskesmas). 


\section{HASIL DAN PEMBAHASAN}

Pemanfaatan bahan makanan lokal dalam bentuk snack kroket dilakukan dalam penelitian ini, dengan temuan-temuan sebagai berikut :

\section{Nilai empiris energi dan zat gizi}

Taraf Perlakuan didasarkan pada Angka Kecukupan Gizi balita usia 1-3 tahun 2019 yaitu sebesar 1350 Kkal (AKG, 2019). Pada formulasi Kroket ini menggunakan kebutuhan untuk snack yaitu $10 \%$ dari total kebutuhan energi per 1 kali pemberian sehingga diperoleh energi sebesar $135 \mathrm{kkal}$. Analisis nilai gizi disajikan pada tabel 1.

Tabel 1. Hasil analisis nilai gizi

\begin{tabular}{lcc}
\hline Nilai Gizi & $\mathrm{P} 1$ & $\mathrm{P} 2$ \\
\hline Energi (Kkal) & 156 & 125 \\
Protein (g) & 7.6 & 8.85 \\
Lemak (g) & 6.36 & 2.76 \\
Karbohidrat (g) & 22.8 & 15.81 \\
Vitamin C (mg) & 26.27 & 26.27 \\
Fosfor (mg) & 131.7 & 131.69 \\
\hline
\end{tabular}

Keterangan: Perbandingan kentang : Ikan Lele : Brokoli $\mathrm{P}_{1}=40: 30: 30, \mathrm{P}_{2}=30: 45: 25$

Tabel 1 menunjukkan bahwa taraf perlakuan 1, dan 2 memiliki nilai gizi yaitu energi sebesar $156 \mathrm{Kkal}$, dan $125 \mathrm{Kkal}$. Nilai Protein P1 sebesar 7,6 gram $(38 \%$ dari kebutuhan Total), P2 8,85 gram (40\% dari kebutuhan total), lemak P1 6,36 gram (14\% dari kebutuhan total) dan P2 sebesar 2,76 gram (9\% dari kebutuhan total).

Penambahan protein nabati mampu meningkatkan kandungan protein yang lebih tinggi dibandingkan dengan penambahan hidrolisat protein ikan lele. Namun demikian, nilai cerna bisa lebih tinggi pada produk hewani dibanding nabati (Hoffman \& Falvo, 2004).

Kandungan gizi dalam brokoli (Brassica Oleracea L Var.Italica) cukup tinggi untuk meningkatkan kesehatan tubuh, seperti vitamin $\mathrm{A}$, vitamin $\mathrm{C}$, dan beberapa mineral yaitu thiamin, niasin, kalsium, dan zat besi (Moreno et al., 2008). Menurut
USDA (2011) $100 \mathrm{~g}$ brokoli mengandung kalsium $40 \mathrm{mg}$, tembaga $0,1 \mathrm{mg}$, besi $0,7 \mathrm{mg}$, dan abu $0,8 \mathrm{~g}$.

\section{Mutu protein}

Selain nilai empiris energi, protein, lemak, karbohidrat, vitamin C, dan Fosfor, formula ini juga memperhitungkan mutu protein. Mutu protein suatu bahan pangan ditentukan oleh kandungan asam amino esensial yang susunannya lengkap dan komposisinya yang sesuai dengan kebutuhan tubuh, serta memiliki nilai cerna protein yang tinggi (Annisa \& Afifah, 2015). Pertumbuhan linear anak-anak tergantung pada lempeng pertumbuhan chondral yang diatur oleh mTORCI dan kesediaan asam amino, seperti asam amino essensial Leusin (Baron et al., 2015). Perhitungan mutu protein disajikan pada tabel 2.

Tabel 2. Nilai mutu protein

\begin{tabular}{lcc}
\hline \multicolumn{1}{c}{ Mutu Protein } & P1 & P2 \\
\hline SAA Lisin (\%) & 191.2 & 183.3 \\
SAA Treonin (\%) & 170 & 127.7 \\
SAA Triptofan $(\%)$ & 59.8 & 82.6 \\
SAA Metionin dan Sistein $(\%)$ & 159 & 117 \\
Mutu Cerna (\%) & 94.4 & 93.9 \\
\hline
\end{tabular}


Tabel 2. menunjukkan bahwa skor asam amino (SAA) mencapai di atas 100\% kecuali Triptofan. Mutu Cerna seluruh formula kroket kentang sebesar 93,9 - 94,4. Skor asam amino menunjukkan bahwa banyaknya persentase asam amino essensial dari total asam amino essensial yang terkandung dalam protein bahan makanan yang dapat digunakan oleh tubuh untuk sintesa protein tubuh. Asam amino pada anak tidak terbentuk secara langsung, namun berasal dari makanan yang dimakan (Pillai dan Kurpad, 2012).

Sejalan dengan hasil penelitian Semba et al.(2016), anak-anak dengan stunting memiliki konsentrasi serum yang lebih rendah dari kesembilan asam amino esensial (triptofan, isoleusin, leusin, valin, metionin, treonin, histidin, fenilalanin, lisin) dibandingkan dengan anak tidak terhambat ( $p$ $<0,01)$. Asam amino esensial ini sangat dibutuhkan untuk sintesis sfingolipid dan gliserofosfolipid (de Onis et al., 2013; Breier et al., 2014)

Dalam metode perhitungan ini skor setiap asam amino esenssial dinyatakan sebagai persentase konsentrasi yang terdapat dalam telur utuh (sebagai protein referensi dengan nilai 100) (BPOM, 2019). Sehingga Jika jumlahnya menunjukkan $\geq 100 \%$ produk sudah dalam kategori baik kadar proteinnya. Asam amino dibutuhkan untuk catch up growth dan proses metabolik. Aktivitas sistem kekebalan tubuh juga akan memecahkan asam amino essensial sehingga pertumbuhan terganggu (Nuss \& Tanumihardjo, 2011; Van den Hoek et al., 2015;)

Mutu Cerna formula Kroket berkisar 94,1-95,1. Mutu cerna produk Snack Kroket dipengaruhi oleh mutu cerna bio-assay bahan-bahan penyusunnya. Mutu Cerna didapat dari total konsumsi protein dikali mutu cerna bio-assay dibagi total konsumsi protein.

Net Protein Utilization merupakan perbandingan antara jumlah nitrogen asam amino yang ditahan tubuh dengan jumlah nitrogen protein yang dikonsumsi (BPOM, 2019). Jika skor asam amino $\geq 100$ maka besarnya NPU sama dengan besar mutu cerna yang artinya semua yang dikonsumsi dapat diserap/tahan sempurna oleh tubuh.

\section{Mutu organoleptik}

Kombinasi warna yang menarik, bentuk yang baik, perpaduan yang baik antar tekstur makanan, serta konsistensi yang baik dari makanan dan besar porsi makanan yang disajikan, sangat mempengaruhi selera makan konsumen dan juga mampu membuat konsumen menikmati makanan yang disajikan (Widyastuti \& Pramono, 2014).

\section{Warna}

Tingkat kesukaan Panelis terhadap Warna Snack Kroket disajikan pada gambar 1.

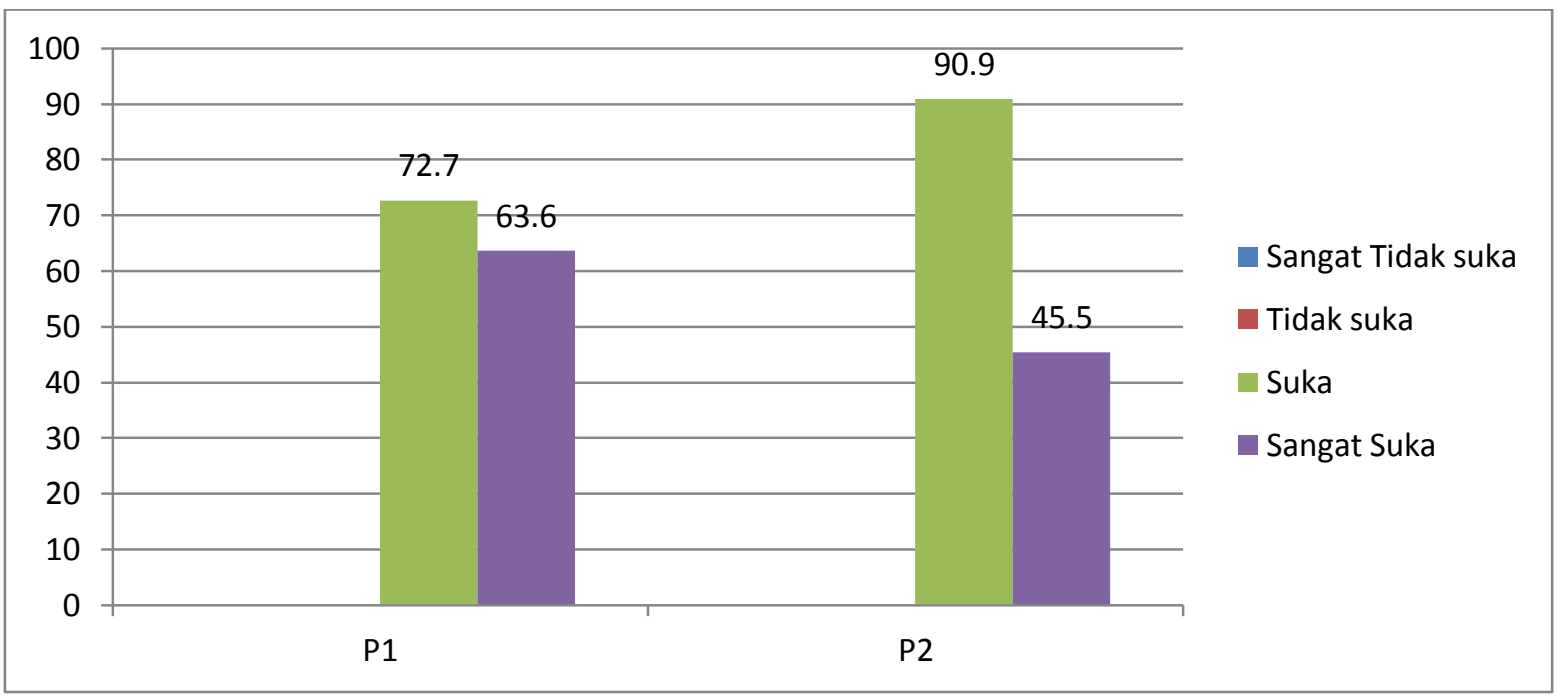

Gambar 1. Tingkat kesukaan panelis terhadap warna kroket 
Gambar 1. menunjukkan bahwa tingkat kesukaan panelis terhadap warna paling tinggi pada perlakuan 1 (P1) yaitu sebanyak $63,6 \%$ sangat suka dan $70 \%$ suka. Warna pada taraf perlakuan P1 paling disukai panelis, dimana proporsi kentang, ikan lele dan brokoli adalah 40:30:30. Kroket kentang berwarna kuning kecokelatan. Penentuan mutu suatu bahan pangan pada umumnya tergantung pada warna karena warna akan dilihat terlebih dahulu sebelum mencicipi makanan, sehingga warna dapat menimbulkan ketertarikan untuk memakan (Ahmadi \& Estiasih, 2009).

\section{Rasa}

Tingkat kesukaan Panelis terhadap rasa snack kroket disajikan pada gambar 2.

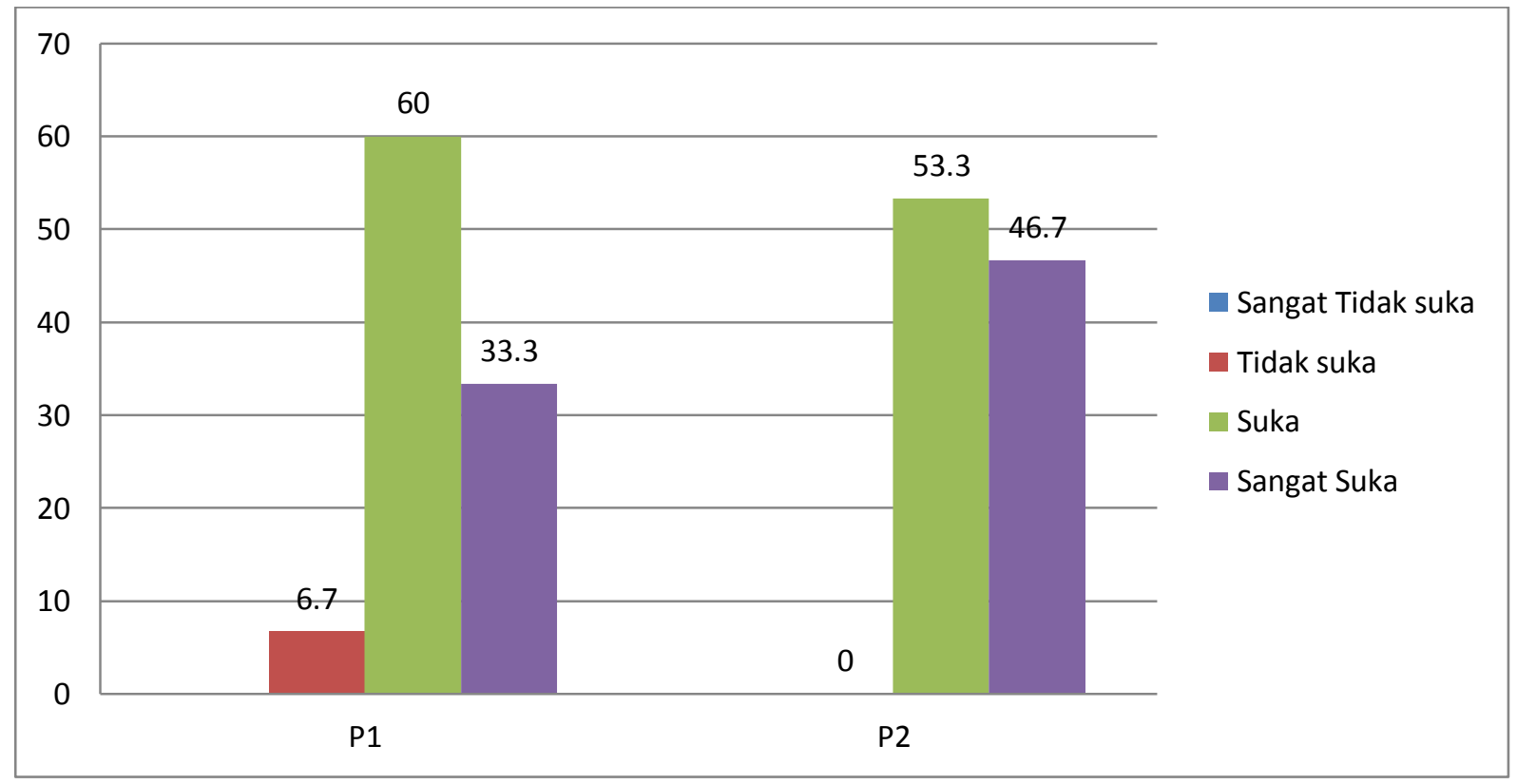

Gambar 2. Tingkat kesukaan panelis terhadap rasa kroket

Gambar 2. Menunjukkan bahwa tingkat kesukaan panelis terhadap rasa paling tinggi pada perlakuan 2 (P2) yaitu sebanyak 53,3\% suka dan $46,7 \%$ sangat suka. Rasa merupakan sensasi yang terbentuk dari hasil perpaduan bahan pembentuk dan komposisinya pada suatu makanan yang ditangkap indra pengecap. Rasa dari Kroket yaitu gurih.

Rasa menjadi salah satu faktor penentu daya terima konsumen terhadap produk pangan. Faktor rasa memegang peranan penting dalam pemilihan produk dan konsumen, karena walaupun kandungan gizinya baik tetapi rasanya tidak dapat diterima oleh konsumen maka target meningkatkan gizi masyarakat tidak dapat tercapai dan produk tidak laku saat dijual di pasaran.

Parameter rasa merupakan parameter penentu dari makanan terasa lezat untuk dikonsumsi. Menurut Lawless (1991), makanan biasanya mengandung lebih dari satu cita rasa dasar dan interaksi gabungan antara rasa dan aroma. Pada penelitian ini cita rasa sedikit amis dan langu masih melekat pada snack kroket akibat penambahan ikan lele dan brokoli, yang sangat mempengaruhi rasa produk.

\section{Tekstur}

Tingkat kesukaan panelis terhadap tekstur snack kroket disajikan pada gambar 3. 


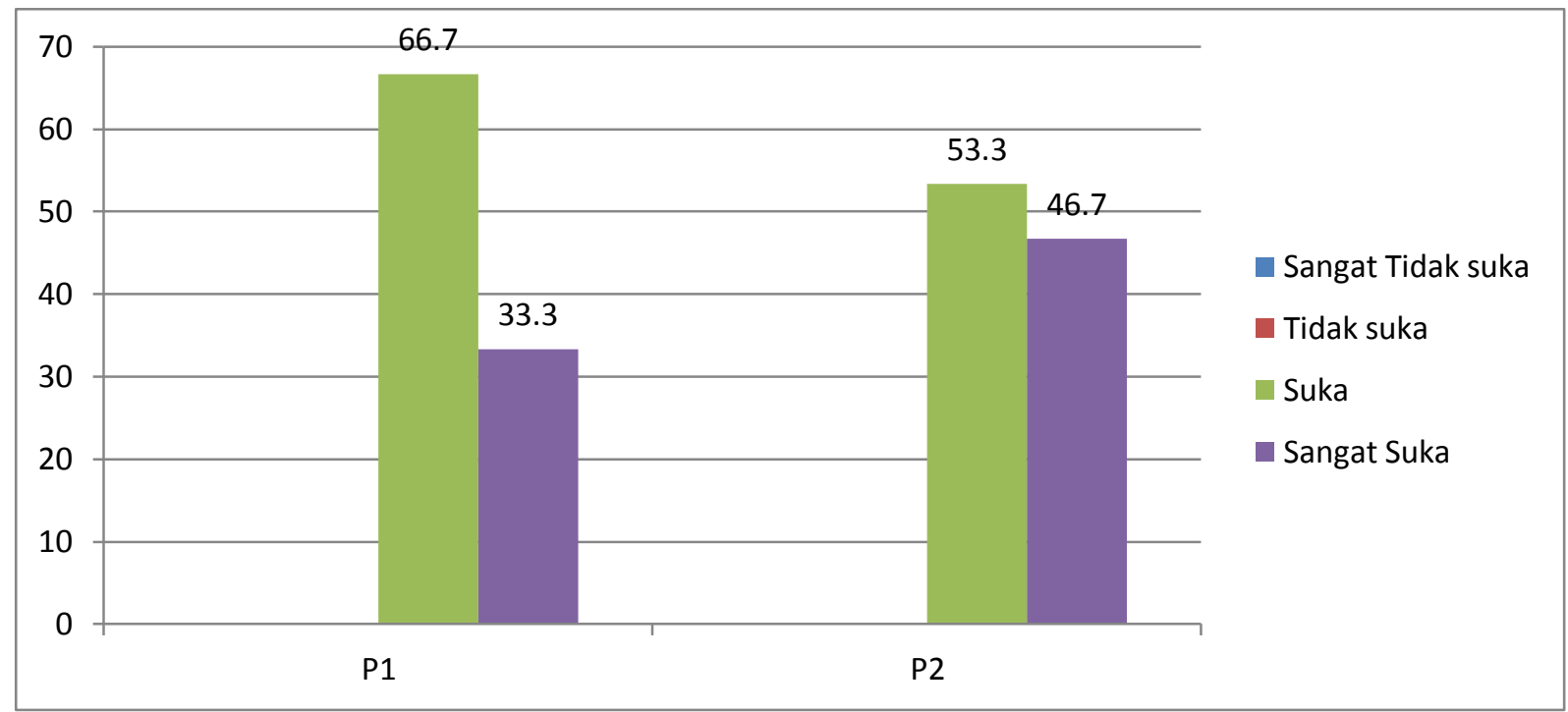

Gambar 3. Tingkat kesukaan panelis terhadap tekstur kroket

Gambar 3. Menunjukkan bahwa tingkat kesukaan panelis terhadap tekstur paling tinggi pada perlakuan 2 (P2) yaitu sebesar $53,3 \%$ suka dan $46,7 \%$ sangat suka. Tekstur dari kroket yaitu lembut di dalam, renyah di bagian luar. Renyah karena ada penambahan tepung panir yang membuat lebih krispi. Tekstur merupakan ciri suatu bahan sebagai akibat perpaduan dari beberapa sifat fisik yang meliputi ukuran, bentuk, jumlah dan unsur-unsur pembentukan bahan yang dapat dirasakan oleh indera peraba dan perasa, termasuk indera mulut dan penglihatan (Midayanto \& Yuwono, 2014).

Menurut Fellows (2000), tekstur makanan kebanyakan ditentukan oleh kandungan air yang terdapat pada produk tersebut. Sedangkan Purnomo (1995) menyatakan bahwa, banyak yang mempengaruhi tekstur pada bahan pangan, antara lain rasio kandungan protein, lemak, suhu pengolahan, kandungan air, dan aktivitas air.

\section{Aroma}

Aroma merupakan sensasi sensoris yang dialami oleh indera pembau. Dalam industri pangan, pengujian aroma atau bau dianggap penting karena dapat memberikan penilaian suatu produk diterima atau tidak. Tingkat kesukaan panelis terhadap aroma snack kroket disajikan pada gambar 4 .

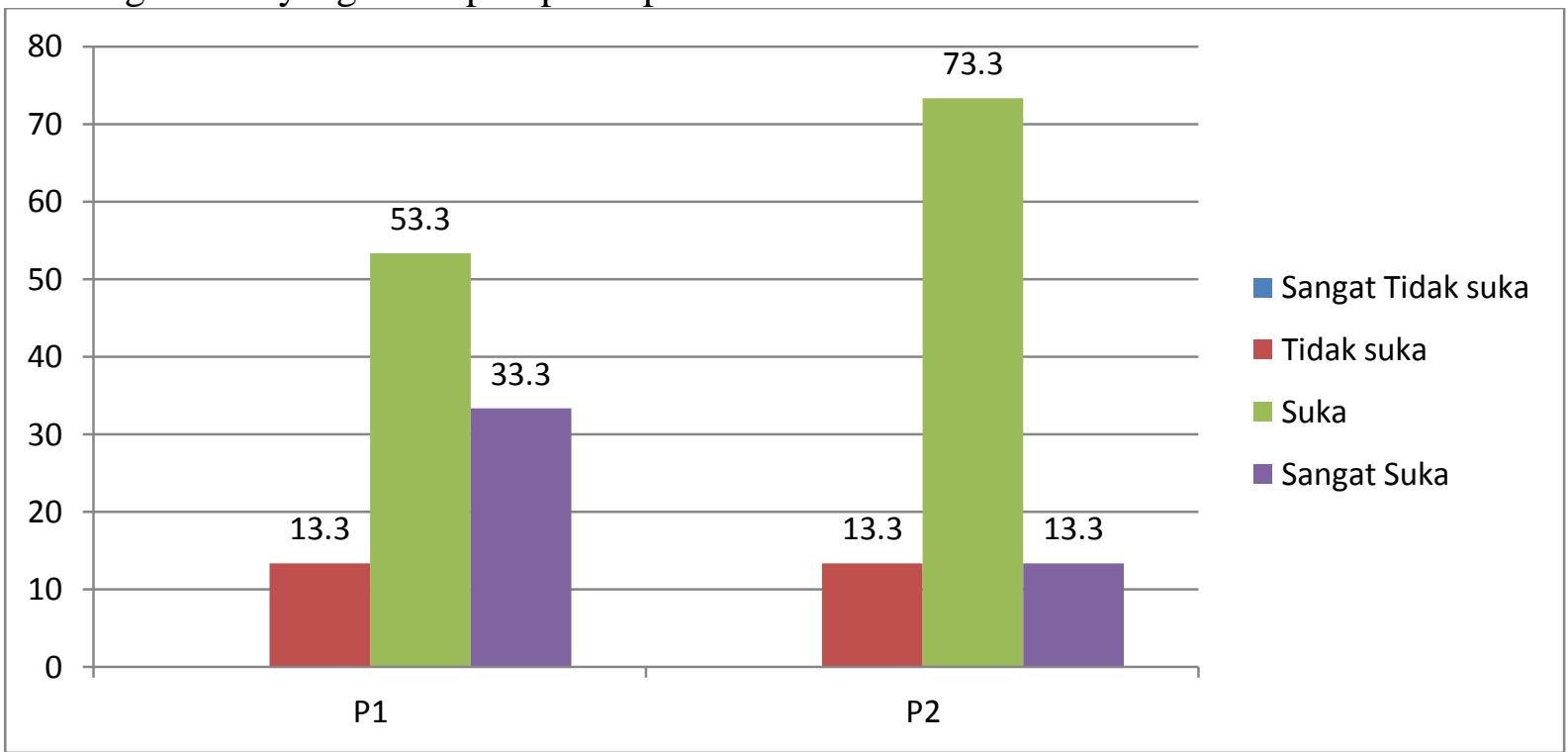

Gambar 4. Tingkat kesukaan panelis terhadap aroma kroket 
Gambar 4 menunjukkan bahwa tingkat kesukaan panelis terhadap aroma paling tinggi pada perlakuan 1 (P1) yaitu 33,3\% sangat suka, 53,3\% suka, dan 13,3\% tidak suka.

Kroket perlakuan satu (P1) diberikan proporsi seimbang antara ikan lele dan brokoli, sedangkan perlakuan dua (P2) proporsi ikan lele lebih banyak dibanding brokoli. Namun sebenarnya aroma dari kedua kroket ini masih ada aroma yang langu dan amis. Hal ini dikarenakan brokoli merupakan tanaman penghasil glukosinolat dari famili Brassicaceae. Glukosinolat merupakan senyawa yang mengandung nitrogen $(\mathrm{N})$ dan belerang (S) hasil metabolit sekunder pada tanaman. Nainggolan et al. (2015) menyatakan bahwa brokoli mengandung sulfur yang menimbulkan bau langu.

Senyawa volatil, yang mudah menguap terdapat pada makanan, mengeluarkan

Tabel 3. Nilai hasil tiap perlakuan

\begin{tabular}{ccc}
\hline Perlakuan & P1 & P2 \\
\hline Jumlah Nh & $0,53^{*}$ & 0,47 \\
Peringkat & I & II \\
\hline
\end{tabular}

Keterangan (*) : Perlakuan Terbaik

Penentuan perlakuan terbaik diperoleh dengan mempertimbangkan beberapa peran variabel penting terhadap mutu produk yang diperoleh dengan pemberian bobot pada masing-masing variabel oleh panelis.

Perlakuan dengan jumlah Nilai hasil (Nh) tertinggi dianggap sebagai perlakuan terbaik karena nilai tersebut diperoleh mempertimbangkan semua variabel yang berperan dalam menentukan mutu produk. Taraf perlakuan P1 (40:30:30) dinyatakan sebagai perlakuan terbaik karena memiliki jumlah Nh tertinggi yaitu 0,53 .

Temuan-temuan dalam penelitian ini dapat dijadikan sebagai dasar pertimbangan untuk memanfaatkan bahan makanan lokal yang ada di sekitar masyarakat sebagai alternatif untuk mengatasi masalah gizi dan kesehatan pada balita dengan status gizi kronis melalui formulasi dan penyediaan snack sehat. Sejalan dengan penelitian Hakimah, et al (2020) bahwa jenis makanan, jenis bahan makanan, kandungan gizi, sensasi bau yang ditangkap oleh indra penciuman yang kemudian ditransmisikan oleh hidung ke lobus penciuman kecil dalam rongga hidung (Lawless, 1991). Kemp et al. (2009) menyatakan bahwa senyawa volatil masuk ke dalam hidung ketika manusia bernafas atau menghirupnya, namun juga dapat masuk dari belakang tenggorokan selama seseorang makan. Senyawa volatil pada penelitian ini terdapat pada aroma ikan lele dan brokoli.

\section{Taraf perlakuan terbaik}

Penentuan perlakuan terbaik diperoleh dengan mempertimbangkan beberapa peran variabel yang penting terhadap mutu produk puding yang diperoleh dengan pemberian bobot pada masing-masing variabel oleh panelis. Nilai hasil tiap perlakuan disajikan pada tabel 3.

penampilan makanan, tekstur makanan, nama menu makanan, dan kesesuaian menu dengan lingkungan menjadi dasar pertimbangan konsumen dalam menentukan preferensinya.

\section{KESIMPULAN}

1. Alternatif Bahan Makanan Lokal dalam pemanfaatan bahan pangan lokal berupa Kentang (Solanum Tuberosum L), Ikan Lele (Clarias, Sp), dan Brokoli (Brassica Oleracea $L$ ).

2. Mutu Gizi (Energi, Protein, Lemak, Karbohidrat). Mutu Protein (DC, SAA, asam amino pembatas), Mutu Organoleptik (Warna, Aroma, Tekstur, Rasa), Penentuan Perlakuan Terbaik, pada perlakuan 1 mempunyai nilai lebih tinggi daripada perlakuan 2 .

3. Penambahan ikan lele meningkatkan kandungan protein dan fosfor pada formula Kroket. Penambahan Brokoli 
meningkatkan kandungan vitamin $\mathrm{C}$ dan fosfor.

4. Hasil uji kesukaan panelis terhadap atribut mutu organoleptik dapat disimpulkan bahwa taraf perlakuan 1 paling disukai, tapi masih memiliki kekurangan pada aroma kroket yang berasa langu sehingga menurunkan tingkat kesukaan panelis.

\section{SARAN}

1. Perlu dilakukan cara pengolahan brokoli yang lebih tepat untuk tetap mempertahankan kandungan gizi dan menghilangkan aroma langu brokoli.

2. Penelitian selanjutnya diharapkan ada inovasi lain dalam pembuatan produk pengembangan formula untuk balita dengan karakteristik masalah gizi Kronis.

\section{UCAPAN TERIMA KASIH}

Ucapan terima kasih kepada Poltekkes Kemenkes Malang, serta para penyusun.

\section{DAFTAR PUSTAKA}

Ahmadi, K., \& Estiasih, T. (2009). Teknologi pengolahan pangan. Jakarta: Bumi Aksara.

AKG. (2019). Angka kecukupan gizi yang dianjurkan untuk masyarakat Indonesia. Peraturan Kementrian Kesehatan Republik Indonesia Nomor 28 Tahun 2019.

Annisa, A., \& Afifah, D. N. (2015). Kadar protein, nilai cerna protein in vitro dan tingkat kesukaan kue kering komplementasi tepung jagung dan tepung kacang merah sebagai makanan tambahan anak gizi kurang. Journal of Nutrition College, 4, 365-371.

Baron, J., Sävendahl, L., De Luca, F., Dauber, A., Phillip, M., Wit, J. M., \& Nilsson, O. (2015). Short and tall stature: a new paradigm emerges. Nature Reviews Endocrinology, 11(12),
735-746.

https://doi:10.1038/nrendo.2015.165.

BPOM RI. (2019). Pedoman evaluasi gizi dan non gizi pangan. Jakarta: BPOM. ISBN: 978-979-3665-42-9. Retrived from:

https://standarpangan.pom.go.id/dokum en/pedoman/Pedoman-Evaluasi-MutuGizi-dan-Non-Gizi-Pangan.pdf

Breier, M., Wahl, S., Prehn, C., Fugmann, M., Ferrari, U., Weise, M., ... \& Lechner, A. (2014). Targeted metabolomics identifies reliable and stable metabolites in human serum and plasma samples. PloS one, 9(2), e89728.

de Onis M., Dewey, K. G., \& Borghi E. (2013). The world health organization's global target for reducing childhood stunting by 2025: rationale and proposed actions. MaternChild Nutr. 9 (2), 6-26.

Hakimah, N., Rahman, N., Sucipto, S., Wignyanto, W., \& Aulanni'am, A. A. (2020). Food services menu engineering: preference, acceptability, and popularity index of local food package menus to control the glycemic responses of $\mathrm{t} 2 \mathrm{dm}$ subjects. Current Nutrition \& Food Science, 16(7), 11191129.

Hoffman, J. R., \& Falvo, M. J. (2004). Protein-which is best?. Journal of Sports Science and Medicine 3(3), 118130.

Kemp, S. E., Hollowood, T., \& Hort, J. (2009). Sensory evaluation: a practical handbook. United Kingdom: Wiley Blackwell. E-book https://onlinelibrary.wiley.com/doi/pdf/ 10.1002/9781118688076.fmatter

Lawless, H. (1991). The sens of smell in food quality and sensory evaluation. Journal of Food Quality, 14(1), 33-60.

Midayanto, D. N., \& Yuwono, S. S. (2014). Penentuan atribut mutu tekstur tahu untuk direkomendasikan sebagai syarat tambahan dalam standar nasional Indonesia. Jurnal Pangan dan Agroindustri, 2(4), 259-267. 
Moreno, D. A., Carvajal, M., LópezBerenguer, C., \& García-Viguera, C. (2006). Chemical and biological characterisation of nutraceutical compounds of broccoli. Journal of pharmaceutical and biomedical analysis, 41(5), 1508-1522.

Nainggolan, R. J., Lubis, L. M., \& Lubis, Z. (2015). Pengaruh perbandingan nenas dengan brokoli dan konsentrasi gum arab terhadap mutu fruit leather. Jurnal Rekayasa Pangan dan Pertanian, 3(1), 83-94.

Nurilmala, M., Nurjanah, \& Utama, R.H. (2009). Kemunduran mutu ikan lele dumbo. Jurnal Pengolahan Hasil Perikanan Indonesia, 12(1), 1-16.

Nuss, E. T., \& Tanumihardjo, S. A. (2011). Quality protein maize for Africa: closing the protein inadequacy gap in vulnerable populations. Advances in Nutrition, 2(3), 217-224. https://doi.org/10.3945/an.110.000182.

Pillai, R., \& Kurpad, A. V. (2012). Amino acid requirements in children and the elderly population. The British Journal of Nutrition. 108(2), 544-549. http://doi.org/10.1017/S000711451200 2401.

Purnomo, A. H. (1995). Aktivitas air dan peranannya dalam pengawetan pangan. Jakarta: UI Press.

Rini, K., \& Hastawati, I. (2017). Uji organoleptik pada pembuatan es krim wortel dengan suplementasi tomat dan brokolisebagai variasi pangan berbahan sayur bagi anak sekolah. Prosiding, 7(1).

USDA. (2011). Nutrien values ad weights are for edible portion of chayote. National Database for Standare Reference Declease. United States of America: United State Database Agriculture. Retrieved from https://data.nal.usda.gov/dataset/compo sition-foods-raw-processed-preparedusda-national-nutrient-databasestandard-referen-14
Van den Hoek, E. K, Sakkas, P., Gerrits, W. J.J, van den Borne, J.J.G.C., van der Peet-Schwering, C.M.C., \& Jansman, A. J.M. (2015). Induced lung inflammation and dietary protein supply affect nitrogen retention and amino acid metabolism in growing pigs. British Journal of Nutrition, 113(3), 414-425. https:doi.org/10.1017/S0007114514003 821.

Widyastuti, N., \& Pramono, A. (2014). Manajemen jasa boga. Yogyakarta: Graha Ilmu. 